\title{
REVIEWS
}

\section{CIRCULATING microRNAs AS A NOVEL CLASS OF POTENTIAL DIAGNOSTIC BIOMARKERS IN NEUROPSYCHIATRIC DISORDERS}

Tatyana M. Kichukova ${ }^{1}$, Nikolay T. Popov ${ }^{2}$, Hristo Y. Ivanov ${ }^{3,4}$, Tihomir I. Vachev ${ }^{1,4 *}$

${ }^{1}$ Department of Plant Physiology and Molecular Biology, Paisii Hilendarski University of Plovdiv, ${ }^{2}$ Male Psychiatric Ward, State Psychiatrical Hospital, Pazardzhik, ${ }^{3}$ St. George University Hospital, Plovdiv, ${ }^{4}$ Department of Pediatrics and Medical Genetics, Faculty of Medicine, Medical University, Plovdiv, Bulgaria

\section{ЦИРКУЛИРУЮЩИЕ МОЛЕКУЛЫ МИКРОРНК КАК НОВЫЙ КЛАСС ПОТЕНЦИАЛЬ- НЫХ ДИАГНОСТИЧЕСКИХ БИОМАРКЕРОВ ПРИ НЕЙРОПСИХИАТРИЧЕСКИХ РАССТРОЙСТВАХ}

\author{
Татяна М. Кичукова ${ }^{1}$, Николай Т. Попов ${ }^{2}$, Христо Й. Иванов ${ }^{3,4}$, Тихомир И. Вачев ${ }^{1,4 *}$ \\ ${ }^{1}$ Кафедра физиологии растений и молекулярной биологии, ПУ „Паисий Хилендарски”, Пловдив, \\ ${ }^{2}$ Мужское психиатрическое отделение для активного лечения, Государственная психиатрическая \\ больница, Пазарджик, 'Отделение медииинской генетики, Университетская больница "Св. Георги”, \\ Пловдив, ${ }^{4}$ Кафедра педиатрии и медицинской генетики, Факультет медиџины, Медицинский \\ университет, Пловдив, Болгария
}

\begin{abstract}
Neuropsychiatric diseases, such as schizophrenia, bipolar disorder (BD), major depressive disorder (MDD) and autism spectrum disorder (ASD), are a huge burden on society, impairing the health of those affected, as well as their ability to learn and work. Biomarkers that reflect the dysregulations linked to neuropsychiatric diseases may potentially assist the diagnosis of these disorders. Most of these biomarkers are found in the brain tissue, which is not easily accessible. This is the challenge for the search of novel biomarkers that are present in various body fluids, including serum or plasma. As a group of important endogenous small noncoding RNAs that regulate gene expression at post-transcriptional level, microRNAs (miRNAs) play a crucial role in many physiological and pathological processes. Previously, researchers discovered that miRNAs contribute to the neurodevelopment and maturation, including neurite outgrowth, dendritogenesis and dendritic spine formation. These developments underline the significance of miRNAs as potential biomarkers for diagnosing and prognosing central nervous system diseases. Accumulated evidence indicates that there are considerable differences between the cell-free miRNA expression profiles of healthy subjects and those of patients. Therefore, circulating miRNAs are likely to become a new class of noninvasive, sensitive biomarkers. Despite the fact that little is known about the origin and functions of circulating miRNAs, their essential roles in the clinical diagnosis and prognosis of neuropsychiatric diseases make them attractive biomarkers. In this review we cover the increasing amounts of dataset that have accumulated in the last years on the use of circulating miRNAs and their values as potential biomarkers in most areas of neuropsychiatric diseases.
\end{abstract}

Key words: neuropsychiatric disorders, circulating microRNAs, biomarkers

Folia Medica 2015;57(3\&4):159-172 Copyright (C) 2015 Medical University, Plovdiv

\section{РЕЗЮМЕ}

Такие нейропсихиатрические заболевания как шизофрения, биполярное расстройство (БР), реккурентное депрессивное расстройство (РДР) и расстройство аутистического спектра (РАС) ложатся огромным бременем на общество, приводят к ухудшению здоровья потерпевших и негативно влияют на дальнейшие возможности для обучения и работы. Биомаркеры, которые выявляют нарушения, связанные с нейропсихиатрическими заболеваниями могут потенциально способствовать диагностированию данных нарушений. Поиск новых потенциальных биомаркеров, находящихся в различных телесных жидкостях, в том числе в сыворотке и плазме, обосновывается тем фактом, что большая часть известных на данный момент биомаркеров находятся в мозговой ткани, которая представляет собой труднодоступный объект для исследований.

Article's history: Received: 10 June 2015; Received in a revised form: 09 July 2015; Accepted: 28 Dec 2015

*Correspondence and reprint request to:T. Vachev, Department of Pediatrics and Medical Genetics, Faculty of Medicine, Medical University, Plovdiv; E-mail: tiho9@abv.bg; Tel.: +359 896026004

15 A Vassil Aprilov Blvd., 4002 Plovdiv, Bulgaria 
В качестве группы важных эндогенных молекул, некодирующих РНК, которые регулируют генную экспрессию на постткранскрипционном уровне, молекулы микроРНК (миРНКи) играют ключевую роль во многих физиологических и патологических процессах. Предыдущие исследования ясно выявили роль молекул микроРНК в развитии нервной системы, дендритогенеза в спинном мозге. Участие молекул микроРНК в данных процессах развития подчёркивает их важное значение в качестве потенциальных биомаркеров для диагностирования и прогноза заболеваний центральной нервной системы с предполагаемыми этиологией и патогенезом развития. Накопившиеся данные в целом ряде различных заболеваний подкрепляют факт существования значительных различий между внеклеточным микроРНК профилем здоровых лиц по сравнению с тем же при пациентах. Следовательно циркулирующие молекулы микроРНК потенциально могут превратиться в новый класс неинвазивных и чувствительных биомаркеров. Тем не менее, до сих пор всё ещё недостаточно изучены происхождение и функции циркулирующих молекул микроРНК, что превращает их в интересные для исследования молекулы, в том числе и их основной роли в клиническом диагнозе и прогнозе нейропсихиатрических заболеваний. В данном обследовании будет охвачен нарастающий набор данных, накопившихся за последние годы, которые нацелены на циркулирующие молекулы микроРНК и на их характеристики в качестве потенциальных биомаркеров в ряде областей нейропсихических заболеваний.

Ключевые слова: нейропсихиатрические заболевания, ичиркулирующие молекуль микроРНК, биомаркеры

Folia Medica 2015;57(3\&4):159-172

(C) 2015 Все права защищены. Медицинский университет, Пловдив

\section{INTRODUCTION}

The complex structure of the nervous system and the capability of the neurons for postsynaptic remodeling require coordination of complicated intracellular networks consisting of molecular signal transduction systems. Owing to the abundance of neural networks, gene variants are capable of causing system dysfunctions exhibiting as associated neurobehavioral syndromes. The importance of different types of non-coding RNAs is increasingly distinguished in this regulatory process, with microRNAs (miRNAs) appearing as a leading candidate in neuropsychiatric field. Previous studies discovered that post-transcriptional gene regulation by miRNA is a key factor in modeling the topography of the neural networks. There is strong evidence that show that miRNAs intervene in neurobiological processes, including neurogenesis, neural differentiation, and synaptic plasticity, as well as neurologic and psychiatric diseases. A close association between miRNA and CNS development and differentiation has been found. In the fully developed CNS, miRNAs are expected to influence the level of messenger RNA in dendrites and to regulate local protein synthesis throughout synaptic plasticity. In addition to keeping the normal physiological functions of the CNS, particular miRNAs are closely related to the appearance and development of CNS disorders. The regulatory mechanisms that arrange the accurate temporal and spatial patterns of gene expression in the brain are at the front line of research for neuropsychiatric disorders.

Discovering biomarkers that are sensitive and reliable enough to allow accurate diagnosis and to be clinically useful is a crucial need. MiRNAs play important role in neurodevelopment and regulation of essential biological processes, thus miRNAs have increasingly been explored, including as biomarkers. MiRNAs are small, non-coding, single-stranded RNA molecules of around 22 nucleotides (nt) in length. As a class of important endogenous molecules they modulate gene expression by recognizing complementary sequences in target messenger RNAs (mRNAs), involved in normal cell function, and modification of gene expression at the posttranscriptional level. ${ }^{1}$ Specific miRNAs have been engaged in a various biological processes like cell development, proliferation, differentiation, and apoptosis. It has been estimated that there are more than 1,000 miRNAs in the human genome and that they regulate up to $60 \%$ of all proteincoding genes. ${ }^{2}$ Each miRNA can target and regulate hundreds of mRNAs. Therefore, the dysregulation of miRNA levels might lead to altered expression and function of many mRNAs, playing a critical role in the pathogenesis of many human diseases.

Some miRNAs may induce the expression of genes that increase cell proliferation and survival, and also inhibit the expression of tumor suppressor genes and/or genes that control apoptosis. Because of this, miRNAs have been explored mostly in the neoplastic processes. MiRNAs that are usually down-regulated in physiological processes, are known as oncogenes or simply "oncomiRs". Increase of their expression promotes neoplasms, or in some cases, evident malignancies. Several 
miRNAs such as miR-155 and miR-17-92 cluster are known as oncomiRs. ${ }^{1}$ For example, miR-17-92 cluster contribute to proliferation, raise angiogenesis and maintain cancer cell survival via post-transcriptional repression of target mRNAs. ${ }^{3}$ Another well described oncomir is $\mathrm{miR}-10 \mathrm{~b}$ that promotes metastasis by suppressing HOXD10, which is negative regulator of a gene associated with tumor cell proliferation and metastasis. ${ }^{4}$ The miRNAs that physiologically up-regulate tumor suppressor genes and/or down-regulate oncogenes and are regarded to cell survival and/or death may be considered tumor suppressor miRNAs because they prevent tumor development. ${ }^{1}$ For instance, let-7 family as a tumor-suppressor miRNA are downregulated in many malignancies and suppresses cancer growth by targeting several oncogenes and basic regulators of mitogenic pathways, such as RAS and HMGA2. ${ }^{5}$ Many miRNAs function contradictory as oncogenes and tumor suppressor genes depending on the cancer type and cellular background. An example is miR-125b, which was reported to function as either an oncogene or tumor-suppressor gene in different cancer types. In ovarian, thyroid, and oral squamous-cell carcinomas, miR-125b is downregulated and has been shown to suppress cell proliferation and cell-cycle progression. ${ }^{6,7}$ At the same time, miR-125b inhibits apoptosis in neuroblastoma cells in a p53-dependent manner ${ }^{8}$ and advances cell proliferation and invasion in prostate cancer cells.9 MicroRNAs appear to be highly tissue-specific biomarkers, with essential clinical applicability for clarifying the cancer origin of metastases. ${ }^{10}$

These data led to the assumption that the aberant microRNA expression profile in body fluids is part of pathological processes. MiRNA signature reflects physiological and/or pathological conditions more accurately than a mRNA abundance profile, because microRNAs are themselves active molecules that influence gene function, and thus reflect altered physiology more directly. In recent years, miRNAs have been detected in a variety of biological fluids as circulating miRNAs in serum, plasma, saliva, urine, breast milk, seminal plasma, tears, amniotic fluid, colostrum, bronchial lavage, cerebrospinal fluid, peritoneal fluid, and pleural fluid. ${ }^{11,12}$ MicroRNAs assessed either from tumour samples or in biofluids, have appeared as biomarkers for tumor diagnosis, prognosis and prediction of response to treatment. In the following pages we will review the increasing amounts of data that have accumulated in the last years on the use of
miRNAs as neuropsychiatric disorder biomarkers.

\section{BIOGENESIS, SOURCES AND ORIGIN OF CIRCU- LATING CELL-FREE microRNAS}

The biogenesis of miRNAs begins when they are transcribed from intergenic or intronic regions into long primary miRNA precursors, known as pri-miRNAs and are able to function both as pri-miRNAs and mRNAs. ${ }^{13}$ These precursors are cleaved inside the nucleus by the components of the microprocessor complex, that contains Drosha and Dgcr8, and are processed into a hairpin precursor called premiRNAs. Pre-miRNAs are afterwards exported into the cytoplasm by nuclear transport receptor exportin-5, and have further cleavage by RNaseIII enzyme Dicer to form a short complementary duplex of two miRNA strands. The miRNA duplex is unwound by helicase into a single mature miRNA that is incorporated into a large miRNA-induced silencing complex (miRISC). Very important components of miRISC are the proteins of the Argonaute family (AGO1, AGO2, AGO3, or AGO4), miRISC serves to find and bind to a sequence that at least partially matches the 3'-untranslated regions (3'-UTR) of target mRNA. As a result of an effective binding translational inhibition and/or mRNA cleavage occurs with regulatory mechanisms that are still not fully understood. ${ }^{14,15}$ MiRNAs are known to limit the expression of their target genes in given cell types and also to 'fine tune' the levels of coexpressed targets, by miRNA-mediated control of gene expression. Thus a desired biological response can occur. MicroRNAs can be exuded in the circulation by two different pathways: energy-free passive release or active and selective secretion in response to different stimuli. The first process does not need energy and occurs after cell destruction in pathological conditions such as apoptosis, metastasis or inflammation and it does not play a major role in the production of circulating miRNAs. ${ }^{16}$ The process of active secretion of miRNAs is ATP and temperature-dependent. It is similar to the discharge of hormones and cytokines, with or without cell stimulation. ${ }^{16}$ Extracellular miRNAs can be packaged in microvesicles (MVs) (exosomes, microparticles (MPs), and apoptotic bodies (ABs)) or can exist as microvesicles-free miRNAs that can be associated with diverse multi protein or lipoprotein complexes. Circulating miRNAs displayed notable stability ${ }^{11}$ and resistance to degradation from endogenous RNAse activity. ${ }^{17}$ It has also been shown that serum miRNAs stay stable after being exposed to severe conditions that would normally degrade most 
RNAs, such as boiling, very low or high $\mathrm{pH}$ levels, extended storage, and 10 freeze-thaw cycles. ${ }^{18}$ This stability can be partially explained by the discovery of lipoprotein complexes, including microvesicles $(30-100 \mathrm{~nm})$, containing miRNAs, ${ }^{19}$ mRNAs, ${ }^{20}$ and proteins ${ }^{20}$. Exosomes are $50-90 \mathrm{~nm}$ vesicles with endocytic origin. ${ }^{21}$ They are accumulated within the multivesicular bodies of the late endosome and exuded by fusion with the cell membrane. In reply to cell stimuli occurs budding of endosomes. Exosomes contain significant amounts of RNA, ${ }^{22}$ including both mRNA and miRNAs. ${ }^{19,23-25}$ All in all 121 miRNAs were identified in exosomes from mast cells and the expression of some miRNAs was higher in microvesicles than in the parental cells. ${ }^{19}$ As distinct, selective retention of specific miRNAs that are not exuded into the extracellular environment has been reported in cancer, suggesting that miRNAs can be selectively packed. ${ }^{23}$ On the other hand MPs are larger than exosomes $(>100 \mathrm{~nm}$ diameter) and are released through plasma membrane budding and also contain miRNAs. ${ }^{26-28}$ Primarily, different stimuli alter the release of miRNAs in MPs, proposes that the miRNA export in MPs is an actively regulated process as in exoxomes. ${ }^{29-31}$ ABs are larger in size than MPs and are generated in response to apoptotic stimuli ${ }^{32}$ and have been involved in tissue repair and angiogenesis. ${ }^{33}$ It has been demonstrated that MVs (exosomes, MPs and $\mathrm{ABs}$ ) are implicated in the intravesicular transport of circulating miRNAs (Fig. 1). ${ }^{19,26,34}$

On the other hand, several studies suggested that high-density lipoprotein (HDL) apart from its classical role as a carrier for excess cellular cholesterol also acts as a transporter of endogenous miRNAs. Native HDL by association with microvesicles-free miRNAs functions as a depot for circulating miRNAs in plasma and enables their transport and delivery to recipient cells. ${ }^{35}$ It was exhibited that highly purified HDL is abundant to small RNA molecules, 15-30 nucleotides in length. Extracellular miRNAs functions in exosome-independent manner, by its association with RNA-binding proteins including Ago2 and Nucleophosmin 1 (NPM1). Argonaute2 (Ago2) is part of the miRNA silencing complex. Association of miRNAs with Ago2 protein, shows that this binding protects and increases the stability of leaked miRNAs. ${ }^{36}$ Ago2 is not the only miRNA-binding protein. Wang et $\mathrm{al}^{37}$ discovered that other RNA binding proteins, such as NPM1, can preserve miRNAs from degradation, playing a role in the wrapping and exporting of miRNAs. The role of the other RNA-binding proteins is currently unclear. Excepting their potential as biomarkers, it

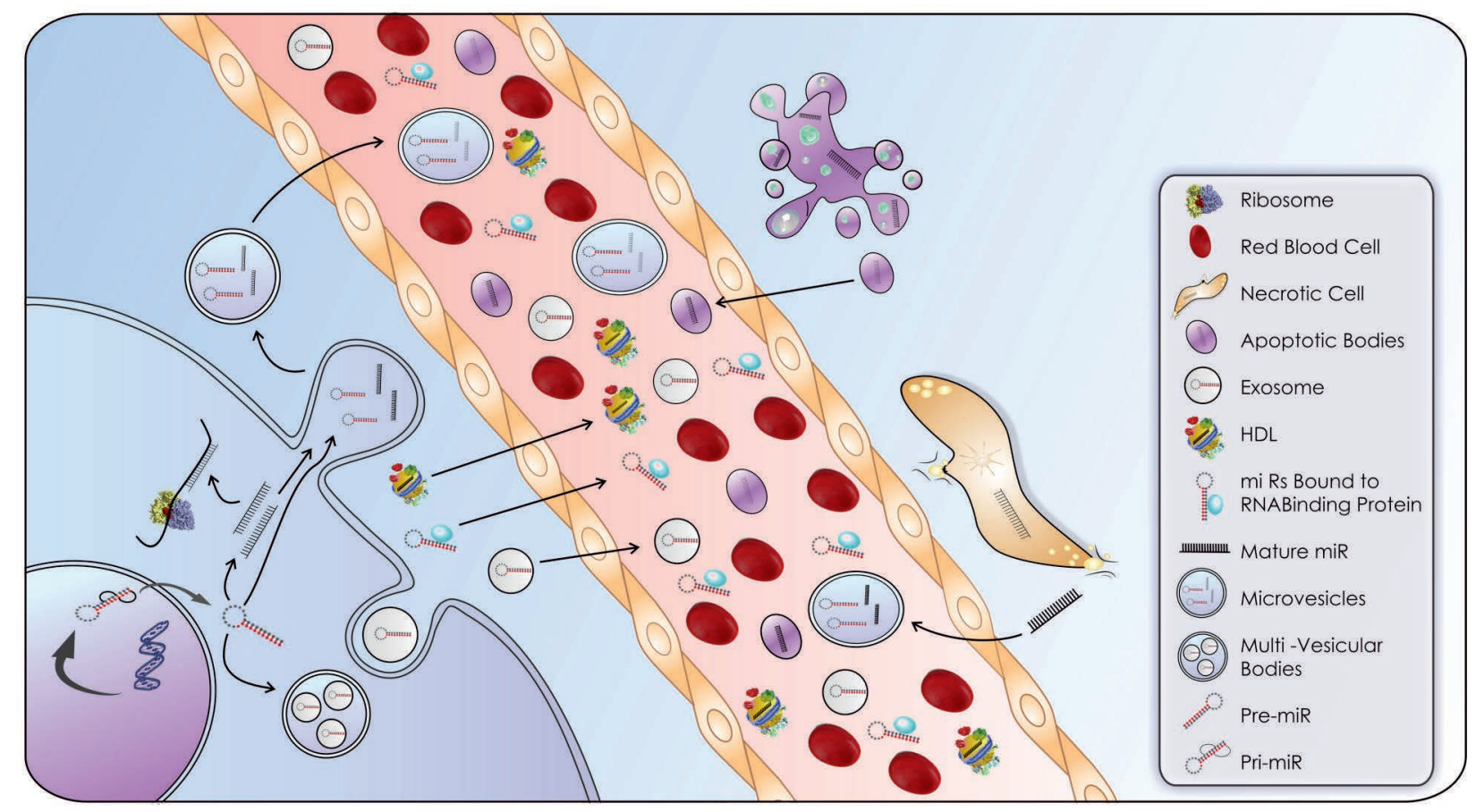

Figure 1. Compartmentalization of circulating miRNAs and putative sources of circulating microRNAs. Although various tissues contribute to the circulating miRNA pool, most miRNAs are probably derived from blood cells. MiRNAs in circulation may originate from necrotic or apoptotic cells, secretory vesicles such as microvesicles or exosomes in protein complexes and in lipoprotein complexes (HDL complexes). 
is intriguing that circulating miRNAs may function as a delivery vehicle and could play role in modulating cell function. Interaction of exosomes with receiver cells is thought to originate through receptor-ligand interactions. ${ }^{38}$ In an in vivo model that allowed close monitoring of miR-16 activity, nude mice were injected with cells engineered to express a reporter for the $3^{\prime} \mathrm{UTR}$ of B-cell lymphoma 2, a validated target of miR-16. Following intratumour injection of exosomes obtained from HEK293 cells overexpressing miR-16 led to suppression of luciferase activity. Control exosomes were ineffective in regard to bioluminescence. These data display that exosomal miR-16 brought its inhibitory ability on its target gene to the recipient cells in vivo. ${ }^{39}$ Direct delivery of miRNAs to receiver cells can also occur by HDL. This happens through a ceramide signalling pathway dependent manner. The miRNAs within HDL changed the cellular miRNA pool and were functional by a loss of relevant miRNA targets. Thus, besides the well-known role of HDL for reverse cholesterol transport, its miRNA content might have biological feasibility. ${ }^{35}$ It is suggested that Ago2 may not just be a vehicle of circulating miRNAs, but a miRNA-protein complexes which has a functional role in silencing gene regulation in receiver cells. ${ }^{36}$ However, there is still no convincing data on the functional role of endogenous extracellular miRNAs in vivo have not been declared.

\section{ADVANTAGES AND DISADVANTAGES OF SERUM MIRNAS AS POTENTIAL BIOMARKERS}

For the categorization of serum miRNAs as biomarkers with transcendent properties, it is very important circulating miRNAs to show sufficient predictability and the capacity to be examined during disease and prognosis. The ease of obtaining and detecting the biomarker from clinical specimen is also important. Lately, protein-based biomarkers in serum have been recognized as attractive candidates for diagnosing various diseases. However, the variety of posttranslational modifications, the sequence differences among various tissues and specimens, and the problems in developing suitable high-affinity and high-sensitivity methods complicate the clinical diagnostic process. Circulating miRNAs have become novel and promising biomarkers in establishing the diagnosis of various diseases because of the limitations of other methods and the following advantages: (1) in contrast to other nucleic acid molecules that cannot exist in an extracellular milieu without being damaged, circulating miRNAs show an unexpected stability in different body fluids. MiRNAs can stay stable not only in the RNase-rich blood environment, but also in extreme conditions, including boiling temperatures, high or low $\mathrm{pH}$, long storage, and freeze-thaw cycles ${ }^{18}$; (2) most miRNAs sequences are specific among different species and have been detected in various tissues, and miRNAs can easily be detected using quantitative reverse transcription-polymerase chain reaction (qRT-PCR); (3) miRNAs expression is tissue or cell-specific and is changed during the pathophysiologic processes. It is very important that altered miRNAs expression profiles in circulation reflect the changes in diseased tissues; (4) serum miRNAs extraction is a noninvasive and simple process; (5) miRNAs have a low complexity which enables exploration. These advantages demonstrate that circulating miRNAs can be useful candidates for diagnosis and other clinical applications in human diseases. Still, there are several challenges that have to be overcome in order to successfully use miRNAs as potential biomarkers. Because one miRNA can target many proteins and one protein can be regulated by many miRNAs, there is intrinsic complexity in the relation between a single miRNA and a pathogenic protein. Thus, analyzing combinations of multiple miRNAs, rather than a single miRNA, may increase the sensitivity and specificity of the diagnosis. In addition, because biofluids contain very low amount of circulating miRNAs, extracting miRNA from serum or plasma is technically challenging. Another major challenge for the analysis is the choice of suitable endogenous controls. Data normalization is another crucial question. Therefore, it is of vital importance to develop standardization methods for quantification of the circulating miRNA. Regardless of these obstacles, the practical value of circulating miRNAs in different diseases is gradually being revealed.

\section{METHODS FOR ANALYSIS OF CIRCULATING miRNAs}

A variety of techniques have been used for isolation and profiling of miRNAs. Purification and extraction of total RNA is derived through variously named "Tri-reagents" (acid phenol in combination with guanidinium-thiocyanate and chloroform). Having in mind that the interest is concentrated on the quantification of specific miRNAs in diverse conditions, the method of choice should exclude any variation in the purification of miRNAs from the samples. Uncovering that in Tri-reagents protocols for RNA purification, short structured miRNAs with low GC content are lost when a small number of cells are 
used ${ }^{40}$ alarms about the accuracy of comparisons of miRNA levels between cell types with different densities. Deep sequencing (next generation sequencing), miRNA microarrays and quantitative reverse transcription polymerase chain reaction (qRT-PCR) approaches are currently used for miRNA profiling. Next generation sequencing (NGS), ${ }^{41}$ gives precise and sensitive miRNAs quantifications and allows the identification of disease specific miRNAs fingerprints. Furthermore, NGS is an outstanding method for discovering unknown miRNAs, as opposed to microarrays and qRT-PCR methods, which can only detect already known miRNAs. However, NGS techniques are unsuitable for routine analysis because of the expensive equipment that is required to perform these. So far, most of miRNA profiling analysis have been done using microarrays and have provided signatures consisting in few to several (530) differentially expressed miRNAs. ${ }^{42}$ However, the use of microarrays for screening the distinct miRNAs represents problems of cross-hybridization between members of miRNA families and dissimilarities in comparing results obtained with different microarray platforms. ${ }^{43-52}$ Currently, a general strategy to validate the microarray data by qRT-PCR guarantees high sensitivity and specificity. Thus, all the data derived by microarray and NGS profiling needs to be transformed into clinical trials by elaborating an easily performed and useful assay that can analyze the specific miRNAs for diagnostic and prognostic purposes. To date these analysis have been relying on qRT-PCR assays. Several variations of RT-PCR have been developed, such as stem-loop RT-PCR ${ }^{53}$ and poly (A)-tailed RT-PCR, which have improved the specificity and sensitivity of miRNA detection. ${ }^{54,55}$ Additionally, qRT-PCR is the most easily performed and cost-effective technique and it is therefore the method of choice when it comes to measuring the

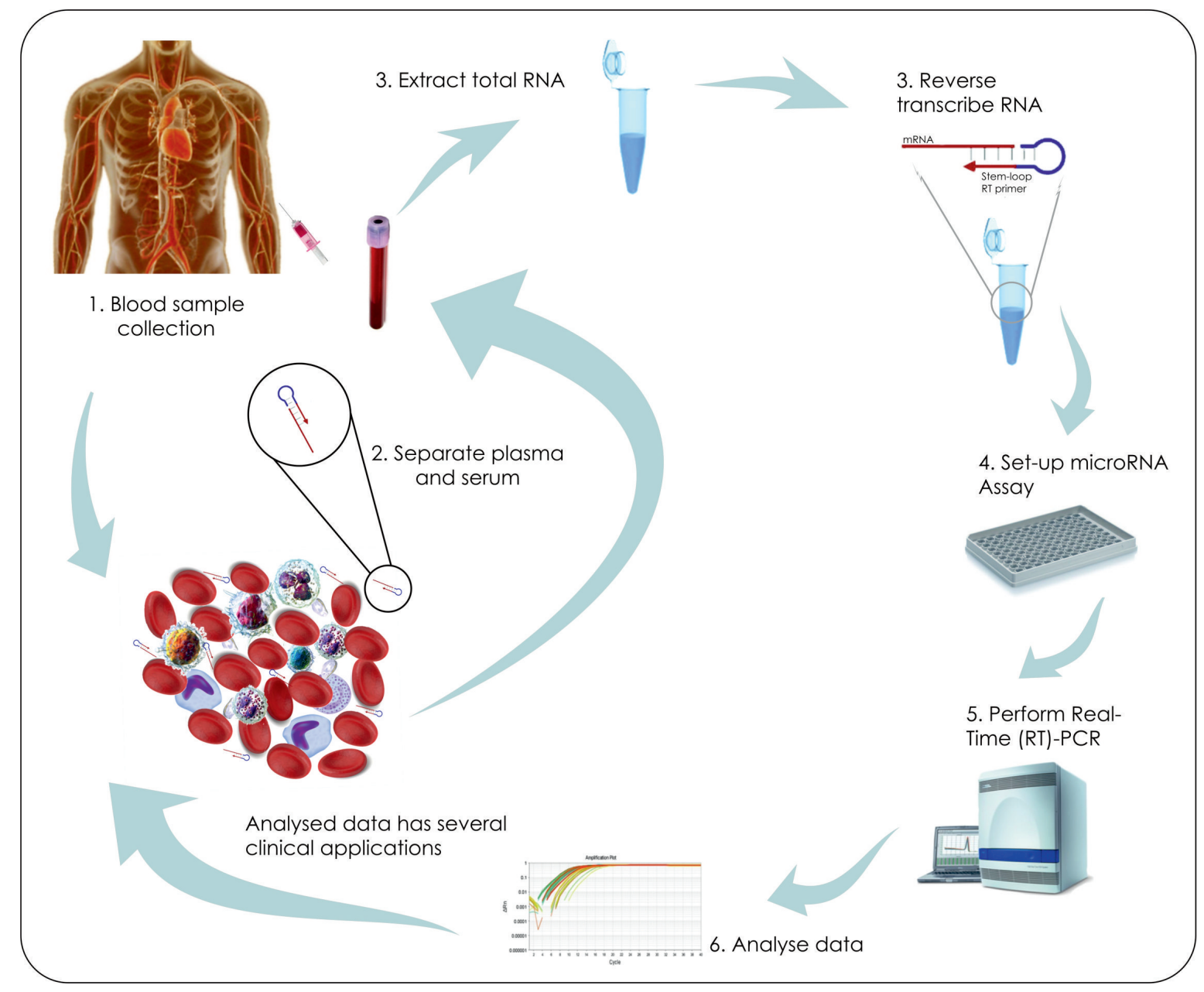

Figure 2. Circulating miRNAs as a diagnostic biomarker in complex neurodevelopment disorders including ASD. Diagram visualising process of minimally invasive procedure. 1) Patients enrolment and blood collection, 2) Extraction of cell-free circulating total RNA, 3) Stem-loop Reverse Transcription of circulating miRNAs, 4) Set-up microRNA Assay, 5) miRNA specific Real-Time PCR for quantification of miRNA levels, 6) Analyse data using SPSS software. 
levels of the limited number of miRNA biomarkers in various specimens in the clinical setting. qRT-PCR assesses the relative levels of varying target miRNAs in comparison with one or more stably expressed reference genes (sometimes called housekeeping or endogenous control genes) which are used to normalize the difference of experimental efficacy among diverse specimens. The choice of suitable normalization control has been a great challenge for quantification of miRNA levels in qRT-PCR methods since some of the small RNAs used as an endogenous control are found in extreme low concentrations in serum and plasma and they are not widely accepted endogenous control for cellfree fluids (Fig. 2).

Ribosomal RNAs (rRNAs) have been used as a normalization control in miRNA studies. ${ }^{56,57}$ Nonetheless, rRNAs can be expressed at much higher levels than the target RNA which makes it difficult to quantify an rRNA and a rare transcript in the same RNA dilution. Moreover, there is data of rRNA dysregulation in apoptosis ${ }^{58}$ and cancer $^{59}$. The most frequently used reference RNA in miRNA qRT-PCR assays is the small nuclear RNA U6 (U6 snRNA) ${ }^{60}$ However, using U6 snRNA to normalize miRNA levels is arguable because of its bigger size (106-107 nt) which might deviate from miRNAs with respect to efficiency of its extraction, reverse transcription and PCR amplification. U6 snRNA has been used as an endogenous control for miRNA studies and in most of the cases U6 cannot ensure constant expression under all experimental conditions. Having in mind the importance of the right selection of a suitable reference gene, U6 snRNA is not a proper choice for miRNA quantification. ${ }^{61}$ Other often used reference genes are snoRNAs, but they too might be dysregulated in cancer. ${ }^{62}$ Several authors have proposed the use of normalization control a combination of miRNAs whose levels are constant in the specific tumor tissue under investigation. For instance, in fresh-frozen lung cancer samples, Peltier and Latham ${ }^{61}$ recommend the use of a combination of miR-191 and miR-103 as normalization controls. Five miRNAs (miR-320d, miR-101-3p, miR-106a-5p, miR-423-5p, miR-93-5p) based on microarray data and U6 have been distinguished as acceptable reference genes. The results of the merged data from four statistical algorithms suggested that the most adequate microRNAs examined for normalization were miR-101-3p and miR-93-5p. Evaluation of the validity of the selected reference genes confirms the acceptability of applying the combination of miR-101-3p and
miR-93-5p as optimal references genes.

The addition of synthetic versions of miRNAs (spike-in control) from other organisms such as $C$. elegans in serum specimens has proven helpful for normalizing the information received by qRT-PCR and also may present an intriguing approach to normalization issues. However, more studies are needed for the identification of a precise stable exogenous miRNA control for each type of body fluid. One of the latest addition to the detection methods for miRNAs is droplet digital PCR (ddPCR) ${ }^{63}$, a method especially beneficial for low abundance miRNAs. In ddPCR, single cDNA molecules are divided evenly among hundreds of individual droplets in which they are amplified to generate binary calls. Using this method researchers can get an absolute readout of total DNA copy number, and thus avoid the need for an endogenous reference gene. Comparison of miRNA quantification by ddPCR and real-time PCR revealed greater precision and improved reproducibility of ddPCR but with comparable sensitivity. Applying ddPCR to serum miRNAs biomarker analysis results in superior diagnostic performance. The ddPCR strategy has many potential advantages over standard real-time PCR including the capability to obtain absolute quantification without the need of external references and validity to variations in PCR efficiency. The future of cell-free miRNA analysis is populated with protein and semiconductor nanopore technologies promising extraordinary capacity in the research of miRNA. The technology looks promising but still does not result in rapid alterations of sequencing methods by a disruptive platform.

\section{CELLULAR AND CIRCULATING miRNAS IN NEUROPSYCHIATRIC DISORDERS}

There is considerable evidence supporting the hypothesis that miRNA plays a crucial role not only in human brain development, but also in brain diseases. ${ }^{64-67}$ Alterations in the sequence of existing miRNAs leads to the alteration of gene regulation, which contributes to the progress of a psychiatric disorder. Understanding the roles of miRNAs will ensure new perceptions for diagnosing and treating CNS disorders. A large amount of studies have examined the potential of circulating miRNAs towards clinical diagnosis and therapy measurements in various CNS disorders, particularly Alzheimer's disease (AD), Huntington's disease (HD), schizophrenia, bipolar disorder (BD), major depressive disorder (MDD), and autism spectrum disorder (ASD).

Alzheimer's disease is a neurodegenerative 
disorder that is characterized by progressive loss in memory and deterioration of the higher cognitive functions. ${ }^{68}$ Early, precise diagnosis of AD is important to postpone the development of neurodegeneration and dementia. Gain and loss-of-function trials confirmed the inhibitory effect of particular miRNAs on serine palmitoyltransferase, long chain base subunit 1/2 (SPTLC1/2) and discovered their ability to repress $\mathrm{Ab}$ protein expression. Therefore, the levels of miR-137, miR-181c, miR-9, miR$29 \mathrm{a}$, and miR-29b in the serum of subjects with probable $\mathrm{AD}$ and mild cognitive impairment were all down-regulated in comparison with healthy controls. ${ }^{69}$ Members of the miR-9 and miR-29 family have also been indicated to directly regulate BACE1. The down-regulation of miR-9 and miR-29 in $\mathrm{AD}$ patients can increase BACE1 expression. ${ }^{70}$ Furthermore, members of the miR-29 family were shown to be downregulated in the gray matter during early $\mathrm{AD}$ development and associated with the thickness of diffuse amyloid plaques, ${ }^{71}$ sustaining the argument that this miRNA may be one of the neuropathologic trials of AD. Moreover, among abnormally expressed miRNAs, miR-107 is notably reduced in early-onset Alzheimer's disease patients and has been proposed to intensify the process of disease by increasing the expression of the b-side amyloid $(\mathrm{Ab})$ precursor protein cleaving enzyme 1 (BACE1). ${ }^{72}$

Researchers discovered 667 miRNAs from one control and one AD patient and particularly quantified and validated changes in neuronal miR-802 reported as suppressor of caveolin-1 gene. ${ }^{73}$ Despite the fact that some AD-specific miRNAs including some let-7 family members (let-7f, let- $7 \mathrm{~b}$ and let7i), miR-9, miR-181, and miR-29 were detected ${ }^{74}$, the applicability of miRNAs as diagnostic clinical tools for $\mathrm{AD}$ will require large-scale validation and follow-up surveys in major groups of patients. Circulating miRNAs are still very tempting and may be the next generation of promising biomarkers for $\mathrm{AD}$, and after all they may be used for diagnosis of neurodegenerative diseases.

Huntington's disease is a neurodegenerative disease caused by aberrant CAG expansion in the gene encoding the protein huntingtin (HTT). ${ }^{75}$ This dominantly derived disorder is distinguished by widespread mRNA dysregulation in striatal and cortical neurons. Thus, there is need of specific biomarkers to track the disease development and to estimate the efficacy of therapeutic interventions. Lately, analysis of circulating miRNAs have been explored in HD as a new approach to identify novel biomarkers. In addition, other types of transcriptional dysregulation may also display incidence of this disease. For instance, the function of p53 has been discovered as being important in HD and is targeted by miR-34. ${ }^{76}$ Circulating miR-34b has been assessed in the plasma of HD subjects before the manifestation of the symptoms; and it has been proposed to be a novel biomarker for the neurodegenerative disorder.

Schizophrenia is another type of severe neuropsychiatric disorder which is characterized by hallucinations, delusions, anhedonia, and social withdrawal. ${ }^{77}$ Environmental impacts and related genetic susceptibility are thought to be the crucial factors in the pathogenesis of this mental illness. ${ }^{78}$ Several altered expression signatures of miRNAs have been discovered in schizophrenia patients compared with healthy individuals; these expressions may originate from the pathophysiology of the disease. Perkins et al. differentiated the expression of 264 miRNAs from the prefrontal cortex of patients diagnosed with schizophrenia and 21 controls not suffering from a psychiatric illness. ${ }^{79}$ Applying a custom-made miRNA microarray, the authors pointed out that the expression of $15 \mathrm{miR}$ NAs decreased and the expression of one miRNA increased in the prefrontal cortex of the schizophrenia subjects, when compared with the control group. After analyzing the information from the gene database using bioinformatic methods, Shi et al. quantified nine miRNAs in the serum samples of 115 patients diagnosed with schizophrenia and 40 healthy controls. The results suggested that the miR-181b, miR-219-2-3p, miR-346, miR-195, miR-1308, miR-92a, miR-17, miR-103 and let-7g are the key players to reflect the schizophrenia illnesses status. The up-regulation was observed for circulating miR-181b, miR-219-2-3p, miR-1308, and let- $7 \mathrm{~g}$ while the downregulation of only one micro RNAs - miR-195 was detected. The authors deduced that these alterations in the serum level of these miRNAs can represent schizophrenia status and may be used as candidate biomarkers for diagnostic purposes. ${ }^{80}$ Furthermore, miR-137 was established to be highly associated $\left(\mathrm{P}=1.6 \times 10^{-11}\right)$ with schizophrenia in one of the largest genomewide association surveys. ${ }^{81}$ Since miRNAs are key regulators of gene expression, major genetic mechanisms may lead to the phenotypic heterogeneity. Lett et al. ${ }^{82}$ have found that miR-137 plays a significant role in the variation in phenotypes that is considered to have a major role in clinical outcome and treatment response. The re- 
searchers concluded that the results of miR-137 on the phenotypic heterogeneity of schizophrenia might arise via neurodevelopmental gene networks. This monitoring may provide an example for the role of miRNAs in the phenotypic heterogeneity of psychiatric disorders. The regulatory role of miRNAs shows that miRNAs may contribute to the etiology of schizophrenia. ${ }^{83}$ MiRNAs are known to affect intricate gene networks and pathways, which indicates that they may be potential biomarkers when dysregulated.

Bipolar disorder is characterised by repeated episodes of mania and depression. BD might occur from abnormalities of the synaptic plasticity. Rong et al. investigated the plasma miRNA levels received from BD patients who were presenting with manic symptoms. ${ }^{84}$ They discovered that circulating miR134 in drug-free patients with bipolar mania was much lower than that in normal cohorts. The plasma miR-134 level increases gradually in patients on a continuous treatment. These results propose that the decreased plasma miR-134 levels may be directly connected with the pathophysiology and severity of manic symptoms in BD. Plasma miRNA-134 in $\mathrm{BD}$ might be assessed as a potential biomarker that can respond to acute manic episodes and connected with successful mood stabilizers treatment. The connection between miRNA level and the typical symptoms of this disease shows that miR-134 has potential value in diagnosing $\mathrm{BD}$ patients and assessing their therapy. ${ }^{84}$

Major depressive disorder (MDD) is one of the most widespread neuropsychiatric disorders. It is associated with psychosocial impairment, insufficient quality of life, and major disability ${ }^{85}$, morbidity, and mortality ${ }^{86,87}$. As it is known, impaired neural and structural plasticity are closely associated with MDD. ${ }^{88}$ The interest in using miRNAs as potential biomarkers for MDD is increasing. Belzeaux et al. ${ }^{89}$ studied miRNA expression profiles in peripheral blood mononuclear cells (PBMCs) collected from 16 MDD subjects and 13 matched healthy controls at baseline, and 2 and 8 weeks after treatment. A parallel of miRNA expression levels between MDD individuals and control groups at baseline and at 8 weeks showed a similar number of dysregulated miRNAs -14 miRNAs, with 9 miRNAs upregulated and 5 downregulated. These 14 miRNAs include miR-107, miR-133a, miR-148a, miR-200c, miR-381, miR-425-3p, miR-494, miR-517b, miR-579, miR589, miR-636, miR-652, miR-941, and miR-1243. Only two miRNAs showed stable overexpression in MDD subjects during the 8-week follow-up compared with control groups (miR-941 and miR589). They also pointed out miRNAs indicating considerable variations of expression among patients with clinical improvement (7 upregulated and 1 downregulated). These results proposed the potential utility of miRNA expression profiles as biomarkers of major depressive episode evolution. ${ }^{89}$ Moreover, miR-494 and miR-335 are downregulated in the prefrontal cortex of MDD subjects..$^{90}$ These studies suggest that miRNAs can be used not only in diagnosing disorders, but also can be applied for treatment response.

Autism spectrum disorder is neurodevelopmental disorder characterized by defects in reciprocal social interactions and language development and/ or communication, and by restricted interests and repetitive behaviours. ASD is mostly genetic in origin, with most datasets maintaining a polygenic epistatic pattern. ${ }^{91}$ Classical genetic studies have not been effective in detecting suitable candidate genes for ASD, due to the heterogeneous character of this disorder. In addition to the genetic factors, environmental factors also play an essential role in predisposing subjects to ASD. Lately, epigenetic mechanisms, which act at the interface of genes and the milieu, have been characterized as a potential collaborator to the pathogenesis of various neurodevelopmental abnormalities. Epigenetic factors including DNA methylations, histone modifications and miRNAs control heritable alterations in gene expression without changing the DNA sequence. ${ }^{92}$ In this regard, miRNAs have recently appeared as leading epigenetic regulators of a variety of cellular processes. The identification of clinically useful noninvasive biomarkers that could enable early intervention for ASD is a principal purpose in ASD research. Thus, serum miRNAs appear as potential biomarkers of ASD. For example, Mundalil Vasu $\mathrm{M}$ et al. ${ }^{93}$ compared the expression of 125 mature miRNAs in serum of pooled 55 individuals with ASD and 55 age and sex-matched control subjects. Thirteen miRNAs were differentially expressed in ASD patients compared to the control groups. MiR-151a-3p, miR-181b-5p, miR-320a, miR-328, miR-433, miR-489, miR-572, and miR-663a were downregulated, while miR-101-3p, miR-106b-5p, miR-130a-3p, miR-195-5p, and miR-19b-3p were upregulated. The results of the various studies are summarized in Table 1 in which some microRNAs like miR-328 and miR-320a showed the same profile of regulation while other miR-19b-3p and miR-106b-5p did not. These differences in miRNA expression between different studies have not been 
Table 1. Comparison of the results obtained from the autism microRNA expression studies

\begin{tabular}{lllc}
\hline \multicolumn{1}{c}{ mir ID } & Study results & \multicolumn{1}{c}{ Type of samples } & Reference \\
\hline hsa-miR-106b-5p & Down & Brain & {$[94]$} \\
hsa-miR-181b-5p & Down & Brain, lymphoblastoid cell line & {$[94][97]$} \\
hsa-miR-195-5p & Up & Lymphoblastoid cell line & {$[96]$} \\
hsa-miR-19b-3p & Down & Lymphoblastoid cell line & {$[95]$} \\
hsa-miR-320a & Down & Lymphoblastoid cell line & {$[95]$} \\
hsa-miR-328 & Down & Brain & {$[94]$} \\
hsa-miR-663a & Up & Lymphoblastoid cell line & {$[95]$} \\
hsa-miR-106b-5p & Up & Serum & {$[93]$} \\
hsa-miR-181b-5p & Down & Serum & {$[93]$} \\
hsa-miR-195-5p & Up & Serum & {$[93]$} \\
hsa-miR-19b-3p & Up & Serum & {$[93]$} \\
miR let-7b-3p & Down & Whole blood & {$[98]$} \\
miR let-7d-3p & Down & Whole blood & {$[98]$} \\
hsa-miR-320a & Down & Serum & {$[93]$} \\
hsa-miR-328 & Down & Serum & {$[93]$} \\
hsa-miR-663a & Down & Serum & {$[93]$} \\
\hline
\end{tabular}

accounted for as yet. In part the level of certain miRNAs might not reflect the same pattern in the other tissues possibly due to the heterogeneous nature of the samples used in some of the studies.

Five miRNAs showed good predictive power for discerning subjects with ASD. The target genes of these dysregulated miRNAs were enriched in several key neurological pathways. ${ }^{93}$ The effects of age and sex on miRNA expression were also tested by ANCOVA in this study. The different expression of miRNAs in ASD patients and control groups stayed considerable even after modifying for the effects of age and sex. The authors used receiver operating characteristic (ROC) curve analysis to assess the predictive power of differentially expressed miRNAs to discern ASD patients from controls. The conducted analysis showed significant diagnostic measurements of these 13 differentially expressed miRNAs for ASD. High sensitivity was found for five miRNAs: miR-181b-5p, miR-320a, miR-572, miR-130a-3p and miR-19b-3p. It was found that the predicted target genes of the differentially expressed miRNAs could participate in various vital neurological pathways. By a detailed analysis of the target genes and the pathways they are participating, a total of 600 predicted genes and 18 neurological pathways were discovered.

Previous studies have demonstrated a differential expression signature of miRNAs in the postmortem brain $^{94}$, in the lymphoblastoid cell lines and whole blood of ASD patients. ${ }^{95-98}$ The summarized results of these reports demonstrated that miR-181b-5p, miR-195-5p, miR- 320a and miR-328 displayed the same direction of regulation in the brain ${ }^{94}$ as in the lymphoblasts. Nevertheless, miR-181b-5p and miR-328 in the serum showed the same manner of regulation as in the brain. The serum miRNA expression levels are very stable, consistent and resistant to RNase action. ${ }^{18}$ In addition, an ANCOVA showed that contradictory factors such as age and sex did not affect miRNA expression profiling. Thus, miR-181b-5p and miR-328 in serum may become potential biomarkers reflecting the miRNA expression profile of patients with ASD. ROC curve analyses showed significant diagnostic measurements of 13 differentially expressed miRNAs for ASD. High values for susceptibility, specificity and area under the curve were found for five miRNAs: miR-181b-5p, miR-320a, miR-572, miR-130a-3p and miR-19b$3 p$. Thus, these five miRNAs may be successful candidates for circulating miRNA-based prognosis of ASD. ${ }^{93}$ MiRNA can affect gene silencing via translational repression or mRNA degradation. ${ }^{99}$ This mRNA destabilization may change different downstream pathways and induce various observable effects. ${ }^{100}$ These results prognosticated some neurologically relevant canonical pathways for the 
target genes of the five miRNAs that demonstrated a good distinguishing power in ROC analysis. Most of these genes and pathways have already been involved in the pathogenesis of ASD. ${ }^{101-103}$

\section{FUTURE PERSPECTIVES}

In the near future blood-circulating extra-cellular miRNAs have the potential to become highly valuable biomarkers. In particular, the identification of serum miRNA signatures able to distinguish ASD may become an innovative tool to provide pivotal information about the nature of the ASD at the transcriptional level. In this context, circulating miRNAs have been investigated to overcome these limitations and some of the current studies in the field have reported promising results. In conclusion, the compilation of a catalogue of differently expressed ASD-associated miRNAs derived from cell-free fluids should help whether these miRNAs are indeed able to report disease condition. It may be still untimely to apply miRNA in clinical therapies but it will not be long before it could be used for diagnostic purposes.

Currently, it is still difficult to determine the correlation between particular circulating miRNAs and diseases diagnoses. Thus, more additional studies are required. Optimized miRNA-specific panels of different biomarkers should be combined to enhance the effectiveness and exactness of the early detection of CNS disorders. Uncovering of circulating miRNAs opens a new field for diagnosis and therapy evaluation in various diseases.

\section{CONCLUDING REMARKS}

In recent years, there have been reported an increasing number of abnormal expression signatures of circulating miRNAs which have been demonstrated to have potential as biomarkers for neuropsychiatric disorders. The research on circulating miRNA, though, is still in its beginning stages. Many technical problems must be solved such as determining standardization procedures for sample preparation, advancing combined methodologies for detecting and quantifying the circulating miRNAs and optimizing the results elucidation. With the progress of novel techniques and further research investigations, circulating miRNAs undoubtedly show a great promise in diagnosing CNS disorders and evaluating related therapies.

\section{ACKNOWLEDGMENTS}

The authors would like to thank M. Kostova PhD for the contribution of the original figures and illustrations used in this review and M. Mazalovska for the professional comprehensive manuscript editing during preparation of the manuscript. This manuscript was supported by MU - Plovdiv Project № HO-12/2013

\section{REFERENCES}

1. Giacoma De Tullio, Vincenza De Fazio, Nicola Sgherza, et al. Challenges and opportunities of MicroRNAs in lymphomas. Molecules 2014;19:14723-781.

2. Friedman RC, Farh KK, Burge CB, et al. Most mammalian mRNAs are conserved targets of microRNAs. Genome Res 2009;19:92-105.

3. Olive V, Jiang I, He L. Mir-17-92, a cluster of miRNAs in the midst of the cancer network. Int $\mathrm{J}$ Biochem Cell Biol 2010;42:1348-54.

4. Ma L, Teruya-Feldstein J, Weinberg RA. Tumour invasion and metastasis initiated by microRNA $10 \mathrm{~b}$ in breast cancer. Nature 2007;449:682-8.

5. Peter, ME. Let-7 and miR-200 microRNAs: guardians against pluripotency and cancer progression. Cell Cycle 2009;8:843-52.

6. Visone R, Pallante P, Vecchione A, et al. Specific microRNAs are downregulated in human thyroid anaplastic carcinomas. Oncogene 2007;26:7590-5.

7. Nam EJ, Yoon H, Kim SW, et al. MicroRNA expression profiles in serous ovarian carcinoma. Clin Cancer Res 2008;14:2690-5.

8. Le MT, Teh C, Shyh-Chang N, et al. MicroRNA $125 \mathrm{~b}$ is a novel negative regulator of $\mathrm{p} 53$. Genes Dev 2009;23:862-76.

9. Ozen M, Creighton CJ, Ozdemir M, et al. Widespread deregulation of microRNA expression in human prostate cancer. Oncogene 2008;27:1788-93.

10. Rosenfeld N, Aharonov R, Meiri E, et al. MicroRNAs accurately identify cancer tissue origin. Nat Biotechnol 2008;26:462-9.

11. Weber JA, Baxter DH, Zhang S, et al. The microRNA spectrum in 12 body fluids. Clin Chem 2010;56:1733-41.

12.Kosaka N, Izumi H, Sekine K, et al. MicroRNA as a new immune-regulatory agent in breast milk. Silence 2010;1:7.

13. Cai X, Hagedorn CH, Cullen BR. Human microRNAs are processed from capped, polyadenylated transcripts that can also function as mRNAs. RNA 2004;10:1957-66.

14. Krol J, Loedige I, Filipowicz W. The widespread regulation of microRNA biogenesis, function and decay. Nat Rev Genet 2010;11:597-610.

15 . Winter J, Jung S, Keller S, et al. Many roads to maturity: microRNA biogenesis pathways and their regulation. Nat Cell Biol 2009;11:228-34.

16.Zen K, Zhang CY. Circulating microRNAs: a novel 
class of biomarkers to diagnose and monitor human cancers. Med Res Rev 2012;32:326-48.

17. Tsui NB, Ng EK, Lo YM, Stability of endogenous and added RNA in blood specimens, serum, and plasma. Clin Chem 2002;48:1647-53.

18. Chen X, Ba Y, Ma L, et al. Characterization of microRNAs in serum: a novel class of biomarkers for diagnosis of cancer and other diseases. Cell Res 2008;18:997-1006.

19. Valadi H, Ekström K, Bossios A, et al. Exosomemediated transfer of mRNAs and microRNAs is a novel mechanism of genetic exchange between cells. Nat Cell Biol 2007;9:654-59.

20. Smalheiser, NR. Exosomal transfer of proteins and RNAs at synapses in the nervous system. Biol Direct 2007;2:35-49.

21.Camussi G, Deregibus MC, Bruno S, et al. Exosomes/ microvesicles as a mechanism of cell-to-cell communication. Kidney Int 2010;78:838-48.

22. Ratajczak J, Wysoczynski M, Hayek F, et al. Membrane-derived microvesicles: important and underappreciated mediators of cell-to-cell communication. Leukemia 2006;20:1487-95.

23. Pegtel DM, Cosmopoulos K, Thorley-Lawson DA, et al. Functional delivery of viral miRNAs via exosomes. Proc Natl Acad Sci USA 2010;107:6328-33.

24. Pigati L, Yaddanapudi SC, Iyengar R, et al. Selective release of microRNA species from normal and malignant mammary epithelial cells. PLoS One 2010;5:e13515.

25. Ratajczak J, Miekus K, Kucia M, et al. Embryonic stem cell derived microvesicles reprogram hematopoietic progenitors: evidence for horizontal transfer of mRNA and protein delivery. Leukemia 2007;20:847-56.

26. Hunter MP, Ismail N, Zhang X, et al. Detection of microRNA expression in human peripheral blood microvesicles. PLoS One 2008;3:e3694.

27. Yuan A, Farber EL, Rapoport AL, et al. Transfer of microRNAs by embryonic stem cell microvesicles. PLoS One 2009; 4:e4722.

28. Mack M, Kleinschmidt A, Bruhl H, et al. Transfer of the chemokine receptor CCR5 between cells by membrane-derived microparticles: a mechanism for cellular human immunodeficiency virus 1 infection. Nat Med 2000;6:769-75.

29. Mause SF, Ritzel E, Liehn EA, et al. Platelet microparticles enhance the vasoregenerative potential of angiogenic early outgrowth cells after vascular injury. Circulation 2010;122:495-506.

30.Prokopi M, Pula G, Mayr U, et al. Proteomic analysis reveals presence of platelet microparticles in endothelial progenitor cell cultures. Blood 2009;114:723-32.

31.Zhang Y, Liu D, Chen X, et al. Secreted monocytic
miR-150 enhances targeted endothelial cell migration. Mol Cell 2010;39:133-44.

32. Beyer C, Pisetsky DS. The role of microparticles in the pathogenesis of rheumatic diseases. Nat Rev Rheumatol 2010;6:21-9.

33. Hristov M, Erl W, Linder S, et al. Apoptotic bodies from endothelial cells enhance the number and initiate the differentiation of human endothelial progenitor cells in vitro. Blood 2004;104:2761-6.

34.Zampetaki A, Willeit P, Drozdov I, et al. Profiling of circulating microRNAs: from single biomarkers to re-wired networks. Cardiovasc Res 2012;93:555-62.

35. Vickers KC, Palmisano BT, Shoucri BM, et al. MicroRNAs are transported in plasma and delivered to recipient cells by high-density lipoproteins. Nat Cell Biol 2011;13:423-33.

36. Arroyo JD, Chevillet JR, Kroh EM, et al. Argonaute2 complexes carry a population of circulating microRNAs independent of vesicles in human plasma. Proc Natl Acad Sci USA 2011;108:5003-8

37. Wang K, Zhang S, Weber J, et al. Export of microRNAs and microRNA-protective protein by mammalian cells. Nucleic Acids Res 2010;38:7248-59.

38. Cocucci E, Racchetti G, Meldolesi J. Shedding microvesicles: artefacts no more. Trends Cell Biol 2009;19:43-51.

39. Iguchi H, Kosaka N, Ochiya T. Secretory microRNAs as a versatile communication tool. Commun Integr Biol 2010;3:478-81.

40. Kim YK, Yeo J, Kim B, et al. Short structured RNAs with low GC content are selectively lost during extraction from a small number of cells. Mol Cell 2012;46:893-5.

41. Metzker ML. Sequencing technologies - the next generation. Nat Rev Genet 2010;11:31-46.

42. Shen J, Stass SA, Jiang F. MicroRNAs as potential biomarkers in human solid tumors. Cancer Lett 2013;329:125-36.

43. Ach RA, Wang H, Curry B. Measuring microRNAs: comparisons of microarray and quantitative PCR measurements, and of different total RNA prep methods. BMC Biotechnol 2008;8:69.

44. Willenbrock H, Salomon J, Søkilde R, et al. Quantitative miRNA expression analysis: comparing microarrays with next generation sequencing. RNA 2009; 15:2028.

45. Sato F, Tsuchiya S, Terasawa K, et al. Intra-platform repeatability and inter-platform comparability of microRNA microarray technology. PLoS One 2009;4:e5540.

46. Git A, Dvinge H, Salmon-Divon M, et al. Systematic comparison of microarray profiling, real-time PCR, and next-generation sequencing technologies for measuring differential microRNA expression. RNA 2010;16:991-1006. 
47. Sah S, McCall MN, Eveleigh D, et al. Performance evaluation of commercial miRNA expression array platforms. BMC Res Notes 2010;3:80.

48. Pradervand S, Weber J, Lemoine F, et al. Concordance among digital gene expression, microarrays, and qPCR when measuring differential expression of microRNAs. Biotechniques 2010;48:219-222.

49. Yauk CL, Rowan-Carroll A, Stead JD, et al. Crossplatform analysis of global microRNA expression technologies. BMC Genomics 2010;11:330.

50. Wang B, Howel P, Bruheim S, et al. Systematic evaluation of three microRNA profiling platforms: microarray, beads array, and quantitative real-time PCR array. PLoS One 2011;6:e17167.

51. Kolbert CP, Feddersen RM, Rakhshan F, et al. Multi-platform analysis of microRNA expression measurements in RNA from fresh frozen and FFPE tissues. PLoS One 2013;8:e52517.

52. Del Vescovo V, Meier T, Inga A, et al. A crossplatform comparison of affymetrix and Agilent microarrays reveals discordant miRNA expression in lung tumors of c-Raf transgenic mice. PLoS One 2013;8:e78870.

53. Chen C, Ridzon DA, Broomer AJ, et al. Real-time quantification of microRNAs by stem-loop RT PCR. Nucleic Acids Res 2005;33:e179.

54. Fu HJ, Zhu J, Yang M, et al. A novel method to monitor the expression of microRNAs. Mol Biotechnol 2006;32:197-204.

55.Ferdin J, Kunej T, Calin GA. Non-coding RNAs: identification of cancer-associated microRNAs by gene profiling. Technol Cancer Res Treat 2010;9:123-38.

56. Takamizawa J, Konishi H, Yanagisawa K, et al. Reduced expression of the let-7 microRNAs in human lung cancers in association with shortened postoperative survival. Cancer Res 2004;64:3753-6.

57.Kulshreshtha R, Ferracin M, Wojcik SE, et al. A microRNA signature of hypoxia. Mol Cell Biol 2007;27:1859-67.

58. Nadano D, Sato TA. Caspase-3-dependent and -independent degradation of $28 \mathrm{~S}$ ribosomal RNA may be involved in the inhibition of protein synthesis during apoptosis initiated by death receptor engagement. J Biol Chem 2000;275:13967-73.

59. Chan MW, Wei SH, Wen P, et al. Hypermethylation of $18 \mathrm{~S}$ and $28 \mathrm{~S}$ ribosomal DNAs predicts progressionfree survival in patients with ovarian cancer. Clin Cancer Res 2005;11:7376-83.

60.Patnaik SK, Kannisto E, Knudsen S, et al. Evaluation of microRNA expression profiles that may predict recurrence of localized stage I non-small cell lung cancer after surgical resection. Cancer Res 2010;70:36-45.

61.Peltier HJ, Latham GJ. Normalization of microRNA expression levels in quantitative RT-PCR assays: identification of suitable reference RNA targets in normal and cancerous human solid tissues. RNA 2008; 14:844-52.

62. Gee HE, Buffa FM, Camps C, et al. The smallnucleolar RNAs commonly used for microRNA normalisation correlate with tumour pathology and prognosis. Br J Cancer 2011;104:1168-77.

63. Hindson CM, Chevillet JR, Briggs HA, et al. Absolute quantification by droplet digital PCR versus analog real-time PCR. Nat Methods 2013;10:1003-5.

64. Sepramaniam S, Tan JR, Tan KS, et al. Circulating microRNAs as biomarkers of acute stroke. Int J Mol Sci 2014; 15:1418-32.

65. Ma L, Wei L, Wu F, et al. Advances with microRNAs in Parkinson's disease research. Drug Des Devel Ther 2013;7:1103-13.

66. Kumar P, Dezso Z, MacKenzie C, et al. Circulating miRNA biomarkers for Alzheimer's disease. PLoS One 2013;8:e69807.

67. Shi W, Du J, Qi Y, et al. Aberrant expression of serum miRNAs in schizophrenia. J Psychiatr Res 2012;46:198-204.

68. Heese K, Akatsu H. Alzheimer's disease: an interactive perspective. Curr Alzheimer Res 2006;3:109-21.

69. Geekiyanage H, Jicha GA, Nelson PT, et al. Blood serum miRNA: non-invasive biomarkers for Alzheimer's disease. Exp Neurol 2012;235:491-6.

70. Hebert SS, Horre K, Nicolai L, et al. Loss of microRNA cluster miR-29a/b-1 in sporadic Alzheimer's disease correlates with increased BACE1/ betasecretase expression. Proc Natl Acad Sci USA 2008;105:6415-20.

71. Wang WX, Huang Q, Hu Y, et al. Patterns of microRNA expression in normal and early Alzheimer's disease human temporal cortex: white matter versus gray matter. Acta Neuropathol 2011;121:193-205.

72. Geekiyanage H, Chan C MicroRNA-137/181c regulates serine palmitoyltransferase and in turn amyloid beta, novel targets in sporadic Alzheimer's disease. J Neurosci 2011 31:14820-30.

73.Lin DH, Yue P, et al. MicroRNA 802 stimulates ROMK channels by suppressing caveolin-1. Journal of the American Society of Nephrology 2011;22:1087-98.

74. Maes OC, Chertkow, et al. MicroRNA: implications for Alzheimer disease and other human CNS disorders. Current Genomics 2009;10:154-68.

75. The Huntington's Disease Collaborative Research Group. A novel gene containing a trinucleotide repeat that is expanded and unstable on Huntington's disease chromosomes. Cell 1993;72:971-983.

76. He L, He X, Lim LP, et al. A microRNA component of the p53 tumour suppressor network. Nature 2007;447:1130-4. 
77. Oertel-Knochel V, Bittner RA, Knochel C, et al. Discovery and development of integrative biological markers for schizophrenia. Prog Neurobiol 2011;95:686-702.

78. van Os J, Rutten BP, Poulton R. Gene-environment interactions in schizophrenia: review of epidemiological findings and future directions. Schizophr Bull 2008;34:1066-82.

79. Perkins DO, Jeffries CD, Jarskog LF, et al. microRNA expression in the prefrontal cortex of individuals with schizophrenia and schizoaffective disorder. Genome Biol 2007;8:R27.

80. Shi W, Du J, Qi Y, et al. Aberrant expression of serum miRNAs in schizophrenia. J Psychiatr Res 2012;46:198-204.

81. Beveridge NJ, Cairns MJ. microRNA dysregulation in schizophrenia. Neurobiol Dis 2012;46:263-71.

82. Lett TA, Chakavarty MM, Felsky D, et al. The genome wide supported microRNA 137 variant predicts phenotypic heterogeneity within schizophrenia. Mol Psychiatry 2013;18:443-50.

83. Popov N, Stoyanova V, Majirova N, et al. Epigenetic aspects in schizophrenia etiology and pathogenesis. Folia Medica 2012;54:12-7.

84. Rong H, Liu TB, Yang KJ, et al. MicroRNA-134 plasma levels before and after treatment for bipolar mania. J Psychiatr Res 2011;45:92-5.

85. Broadhead WE, Blazer DG, George LK, et al. Depression, disability days, and days lost from work in a prospective epidemiologic survey. JAMA 1990;264:2524-8.

86. Pompili M, Innamorati M, Rihmer Z, et al. Cyclothymic-depressive-anxious temperament pattern is related to suicide risk in 346 patients with major mood disorders. J Affect Disord 2012;136:405-11.

87. Innamorati M, Pompili M, Gonda X, et al. Psychometric properties of the Gotland Scale for Depression in Italian psychiatric inpatients and its utility in the prediction of suicide risk. J Affect Disord 2011;132:99-103.

88. Ota KT, Duman RS. Environmental and pharmacological modulations of cellular plasticity: role in the pathophysiology and treatment of depression. Neurobiol Dis 2013;57:28-37.

89. Belzeaux R, Bergon A, Jeanjean V, et al. Responder and nonresponder patients exhibit different peripheral transcriptional signatures during major depressive episode. Transl Psychiatry 2012;2:e185
90. Smalheiser NR, Lugli G, Rizavi HS, et al. MicroRNA expression is downregulated and reorganized in prefrontal cortex of depressed suicide subjects. PLoS One 2012; 7:e33201.

91. Meek SE, Lemery-Chalfant K, Jahromi LB, et al. A review of gene environment correlations and their implications for autism: a conceptual model. Psychol Rev 2013 120:497-521.

92.Delcuve GP, Rastegar M, Davie JR. Epigenetic control. J Cell Physiol 2009;219:243-250.

93. Mundalil Vasu M, Anitha A, Thanseem I, et al. Serum microRNA profiles in children with autism. Mol Autism 2014;5:40.

94. Abu-Elneel K, Liu T, Gazzaniga FS, et al. Heterogeneous dysregulation of microRNAs across the autism spectrum. Neurogenetics 2008;9:153-61.

95. Talebizadeh Z, Butler MG, Theodoro MF. Feasibility and relevance of examining lymphoblastoid cell lines to study role of microRNAs in autism. Autism Res 2008;1:240-50.

96. Sarachana T, Zhou R, Chen G, et al. Investigation of post-transcriptional gene regulatory networks associated with autism spectrum disorders by microRNA expression profiling of lymphoblastoid cell lines. Genome Med 2010;2:23.

97. Ghahramani Seno MM, Hu P, Gwadry FG, et al. Gene and miRNA expression profiles in autism spectrum disorders. Brain Res 2011;1380:85-97.

98. Vachev T, Minkov I, Stoyanova V, et al. Down regulation of miRNA let-7b-3p and let-7d-3p in the peripheral blood of children with autism spectrum disorder. Int J Curr Microbiol App Sci 2013;2;384-8.

99. Huntzinger E, Izaurralde E. Gene silencing by microRNAs: contributions of translational repression and mRNA decay. Nat Rev Genet 2011;12:99-110.

100. Fabian MR, Sonenberg N, Filipowicz W. Regulation of mRNA translation and stability by microRNAs. Annu Rev Biochem 2010;79:351-79.

101. Suda S, Iwata K, Shimmura C, et al. Decreased expression of axon-guidance receptors in the anterior cingulate cortex in autism. Mol Autism 2011;2:14.

102. Anitha A, Nakamura K, Thanseem I, et al. Downregulation of the expression of mitochondrial electron transport complex genes in autism brains. Brain Pathol 2013;23:294-302.

103. Hu VW, Nguyen A, Kim KS, et al. Gene expression profiling of lymphoblasts from autistic and nonaffected sib pairs: altered pathways in neuronal development and steroid biosynthesis. PLoS One 2009;4:e5775. 